\title{
特集【論説】 不動産をめぐる環境法制の諸問題
}

\section{気候変動の影響と我が国の取組}

The impacts of climate change and Japan's national climate policies and actions

Yuzo YAGAI : Ministry of the Environment, Global Environment Bureau,

Climate Change Policy Division

谷貝 雄三*

\section{1. はじめに}

近年, 地球温暖化問題（気候変動問題）は, 食 料問題や水資源問題，さらには国家間の格差や社 会経済構造の変革と結び付けられ，世界中から大 きな注目を浴びている。すでに，昨年 6 月にドイ ツで開催された，G8ハイリゲンダムサミットに おいて主要な議題として取り上げられ, さらに本 年 7 月に我が国の北海道洞爺湖で開催された $\mathrm{G} 8$ サミットにおいても, 最重要課題として取り上げ られた。

このように国際社会において重要なテーマと なった地球温暖化問題において, 最も基盤となる べき科学的知見を提供しているのが, 世界中の科 学者が集まって構成された「気候変動に関する政 府間パネル」(IPCC) である。昨年, その研究成果 を評価され，映画「不都合な真実」の公開を含め て気候変動問題に熱心に取り組んでいたアル・ゴ ア元米副大統領とともに, ノーベル平和賞を受賞 したことは記憶に新しい。

気候変動問題への研究が, ノーベル「平和賞」
の受賞につながったのは, IPCCが究明を続けて いる気候変動による悪影響（自然災害の増加や水 不足・食糧不足など）が，紛争のリスクを高める ことが改めて認識されたこと, そのため, IPCC等 が示している温暖化対策が，紛争を抑止し，まさ に平和に資するものと評価されたものと考えられ る。あるいは，国際社会が，温暖化対策が，もは や一刻の猶予も許されていないとの危機感を抱い ていることの表れであるともいえる。

このような状況の中で, 我が国は, 昨年から, 世界全体の地球温暖化問題に対する長期目標 （2050年までに全世界の温室効果ガス排出量を半 減以下に削減）の設定と, 京都議定書の次の国際 的な枠組み（ポスト京都）を設計するための諸原 則などを国際社会に向けて提言してきた（※ 1)。 さらに，本年六月には福田総理大臣によって，日 本の積極的な取組を盛り込んだいわゆる「福田ビ ジョン」(※2) が発表され, 本年七月の洞爺湖サ ミットにおいても, 議長国として主要経済国によ る議論をリードした（※3）。

他方で，我が国自身の温暖化対策への取組につ

谷貝 雄三*（やがい ゆうぞう）環境省地球環境局地球温暖化対策課

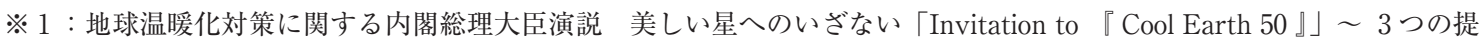
案, 3 つの原則 (平成19年 5 月 24 日)

http://www.kantei.go.jp/jp/abespeech/2007/05/24speech.html

ダボス会議における福田内閣総理大臣特別講演（平成20年 1 月 26 日）

http://www.kantei.go.jp/jp/hukudaspeech/2008/01/26speech.html

※ 2: 福田内閣総理大臣スピーチ「低炭素社会・日本」をめざして (平成20年 6 月 9 日)

http://www.kantei.go.jp/jp/hukudaspeech/2008/06/09speech.html 
いては，着実に進みつつあるものの，排出量の削 減には至らず，今後長期的に大幅な削減を実現す るためには，更なる取組の強化が不可欠である。

以下，地球温暖化がわれわれの社会に与えるさ まざまな影響について, IPCCの報告書を基に俯 㒈し, その上で, 世界中で地球温暖化問題への取 組が進む中, 我が国として今後どのように対策に 取り組もうとしているかを概説する。

\section{IPCC第四次評価報告書による地球温 暖化の影響}

気候変動に関する政府間パネル (IPCC) は, 1988 年に世界気象機関（WMO）と国連環境計画 (UNEP) により設立された国連の組織であり，世 界中の科学者の協力により, 温暖化に関する最新 の知見をまとめ, 政策決定者をはじめ, 広く一般 に利用してもらうことを任務として活動している。

IPCCは，すでに1990年から 3 回（1990年・1995 年・2001年), 温暖化の影響・対策等に関する評価 報告書を公表し, 温暖化問題を提起してきたが, 昨年, 最新の報告書 (第 4 次評価報告書 $(\mathrm{AR} 4)$ ) （※ 4）を発表した。IPCCの報告書は, 数千名に 及ぶ執筆者や専門家の協力のもと, 立場の異なる 約130国の政府による全会一致の結論を得てまと められる。また, 異なる見解についても, 科学的 な確からしさをそれぞれ評価し，科学的知見に基 づいて，レベルを分けて表現されている。そうし た特徵を持ちつつも, 今回のAR 4 は, 温暖化の原 因や影響等について，これまで蓄積された知見を 踏まえ, 相当程度踏み込んだ記述がなされている。

具体的には，例えば，1906年から2005年までの 100 年間で, 世界の平均気温は $0.74{ }^{\circ} \mathrm{C}$ 上昇しており, もはや地球温暖化は疑う余地はないと断定してい
る。また，近年の平均気温の上昇は，過去にあっ た地球温暖化の例と比較しても, 自然要因だけで は説明がつかず，人為起源の温室効果ガスに起因 するものとほぼ断定（90\%を超える確率）してい る。

また, 地球温暖化の影響については, 既に生じ ている影響として,「海面の上昇」(20世紀の100年 間で, 世界平均海面水位が $17 \mathrm{~cm}$ 上昇), 「積雪や水 河等の減少」(北極の海水範囲の年平均值は10年ご とに約2.7\%（2.1～3.3\%）減少),「世界の海洋の 酸性化」等が挙げられている。

今後の温暖化の進行によって, さらに, 生態系 への深刻な影響 $\left(1.5^{\circ} \mathrm{C} \sim 2.5^{\circ} \mathrm{C}\right.$ の気温上昇により, 動植物の $2 \sim 3$ 割で絶滅リスクが増加), 数億人規 模の水不足の一層の悪化, 農業への打撃, 感染症 の増加, 災害の激化など, 私たちの経済・社会活 動に様々な悪影響が複合的に生じる可能性が指摘 されている(図 1)。AR4では, さまざまなシナリ オを想定した上で, 今後100年間で, 地球の気温が さらに $1.8^{\circ} \mathrm{C}$ から $4.0^{\circ} \mathrm{C}$ 上昇するものと予測してい る。また，わずかな気温上昇でも温暖化の悪影響 を被る地域・分野があり, 例えば, 中緯度地域や 半乾燥低緯度地域における水利用可能量の減少や 干ばつの増加, サンゴの白化の増加, 沿岸域にお ける洪水や暴風雨による被害の増加, 感染症の媒 介生物の分布変化など，地域や分野によっては, たとえ $0 \sim 1{ }^{\circ} \mathrm{C}$ 程度の気温上昇であっても, 温暖 化の悪影響を被ることとされている。

こうした状況を鑑みれば，「世界平均で何 ${ }^{\circ} \mathrm{C} の$ 気温上昇であれば安全」という線を引くことは難 しく，可能な限り早期に温暖化を抑制することが 必要となってくる。

※ 3 ： I P C C 第四次評価報告書について（環境省ホームページ）

http://www.env.go.jp/earth/ipcc/4th_rep.html

$※ 4 ： G 8$ 北海道洞爺湖サミット首脳宣言 (2008年 7 月 8 日)

http://www.g8summit.go.jp/doc/doc080714_ka.html 


\section{予測される将来の影響}

\section{O IPCCでは、1980年から1999年までに比べ、21 世紀末（2090年から 2099 年) の平均気温上昇は $1.1 \sim 6.4^{\circ} \mathrm{C}$ と予測}

\section{気温上昗の程度と椂々な分野への影響規模}

気候变化に脆弱な分野においては、たとええ 0 1 ${ }^{\circ} \mathrm{C}$ 気温上昇でも温暖化の悪影響が生じると予測される。

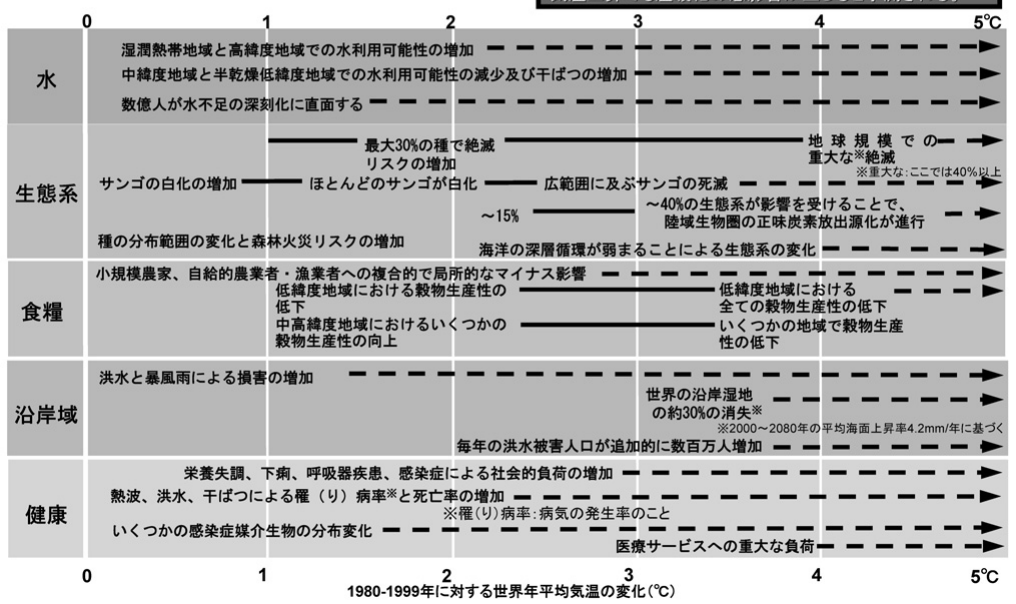

図 1 : 温暖化によって予想される将来の影響

出典 : AR4 SPM

\section{3．温暖化による日本への影響}

日本においても，近年，温暖化の影響ではない かと疑われるさまざまな事象が生じている。例え ば，大型台風の増加による被害の増大であり，あ るいは，昨年日本では最高気温を更新したが，こ うした暑さによって，熱中症患者数は，多くの都 市で過去最高を記録している。加えて，極端に雨 が少ない年の増加や，一方で，時間雨量が100ミリ 以上の豪雨の回数が増加している。また，高山植 物の消失が進むなど，生態系に影響が現れつつあ る。こうした影響は, 温暖化の進行によってさら に強くなるものと考えられる。

さらに今後, 温暖化によって世界全体での食料 生産が減少すれば，食料を輸入に頼っている日本 においては, 食品価格の值上げ等の悪影響が生じ ることとなる。また，日本国内の農業においても， 温暖化によって，コメの品質低下や，麦・大豆の
減収, りんごやみかん等, 果樹の栽培適地の移動 が予測され，水産業や畜産業にも影響が生じるこ とが考えられる。さらに, 感染症を媒介する生物 の生息域が広がり, 感染症のリスクが高まること となる。

\section{IPCC報告書を踏まえた国際的な取組}

AR4では，世界の温室効果ガスの排出量は，先 進国によるエネルギー消費の増大や途上国の経済 成長により，今後著しく増加すると予測されてい る。

地球温暖化問題へ対処するため, 1992年, 国際 社会は，大気中の温室効果ガスの濃度を，危険な 影響を及ぼさない範囲で安定化させることを究極 目的とする,『気候変動に関する国際連合枠組条約 (気候変動枠組条約)』を採択した。さらに，その 重要な第一歩として, 先進国の温室効果ガスの削 減を，法的拘束力を持つものとして約束する京都 


\section{議論の前提：世界全体のCO2排出量と今後の予測}

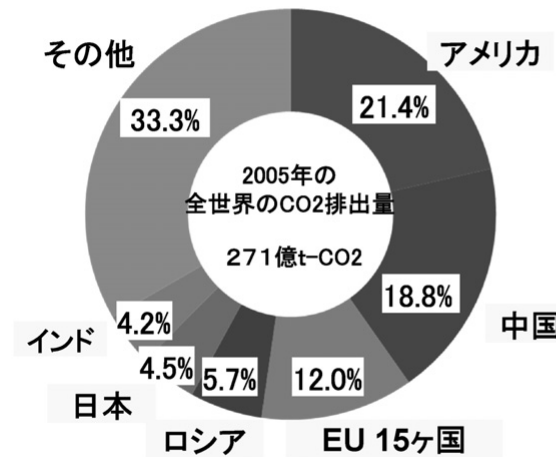

IEA TCO2 EMISSIONS FROM FUEL COMBUSTION 2007 EDITIONより環境省作成

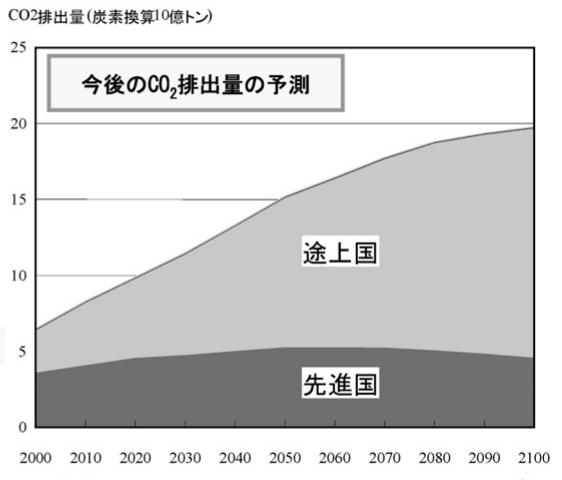

出典: Kainuma et al., 2002:

Climate Policy Assessment, Springer, p.64.

図 2 : 先進国と開発途上国の今後の排出量予測

議定書を1997年に採択した（2005年 2 月に発効）。

京都議定書では, 気候変動枠組条約で示された 「共通だが差異のある責任」に基づき, 温室効果ガ ス (二酸化炭素, メタン, 代替フロンなど 6 種類 のガス）の排出量を，2008年から2012年までの第 一約束期間において, 先進国が一定割合を削減す ることを義務付けており, 日本においては1990年 度比で平均 $6 \%$ の削減が定められている。

すでに現在，世界全体の 1 年間当たりの温室効 果ガスの排出量は, 自然が吸収する量の倍以上に 達しており, 今後, 少なくとも世界の温室効果ガ 又排出濃度が増大しないよう安定化させるだけで も, 早急に全世界の排出量を半分以下にする必要 がある（図 3 )。そのため, これまで温室効果ガス を大量に排出して発展してきた先進国が率先して 対策を講じるとともに, 将来的に先進国の排出量 を上回ると予測されている開発途上国も, 何らか の形で排出削減・抑制に参加することが必要とな る。

その意味で, 先進国に法的な削減義務を課した 京都議定書は, 温暖化対策の重要な一歩であるが, 出発点であって, 今後, 世界全体で, 更なる長期的・
継続的な削減を進めていくことが不可欠である。

AR4では,「今後数十年にわたり, 世界の温室効 果ガス排出量を削減するだけの大きな排出削減ポ テンシャルがあり」,「今後20～30年の温室効果ガ 又排出削減努力とそれに向けた投資が，より低い 安定化濃度の達成に大きな影響を与える」として いる。また，排出削減が遅れると，より甚大な影 響を被るおそれが増大するとも指摘している。 よって, 今後の我々の努力が, 温暖化の影響を抑 える上での鍵となる。

現在, 京都議定書の第一約束期間以降（2013年 〜）の次期枠組みについて，2009年までに合意す ることを目指し, 国際社会において議論が進めら れている。その中で我が国は, 安倍前総理や福田 総理のイニシアティブによって, 世界の排出量を 10年〜20年の間にピークアウトさせ，2050年には 少なくとも半減させること, 各国の事情に応じて 削減量を積み上げ，公平さを確保することなどを 世界に訴えてきた。今回の北海道洞爺湖サミット においても, 議長国として主要経済国の議論を リードし，意見をとりまとめた。その結果，日本 が提案してきた2050年半減の長期目標を, 気候変 


\section{排出量と吸収量のバランス}

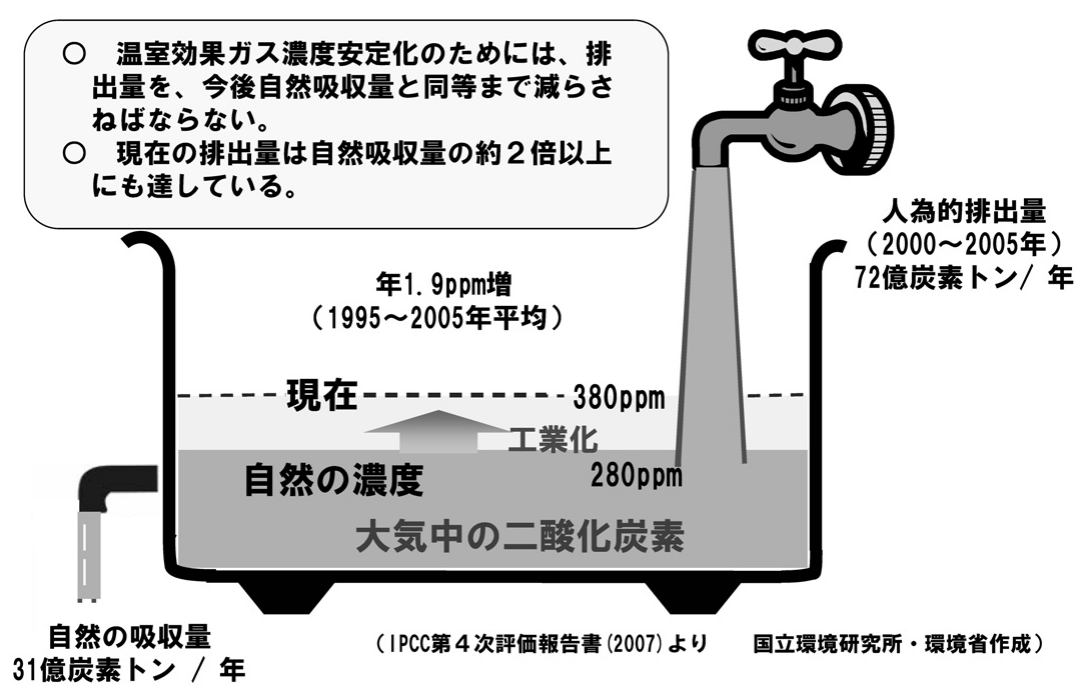

図 3：二酸化炭素濃度の安定化のイメージ

動枠組条約の加盟国において検討・採択すること を求めることとされ，その長期目標を達成するた めには，各国の中期目標と国家計画が必要であり， 特に先進国において, 野心的な中期の国別削減目 標を実施することとされたところである（※ 4)。

今後, さらに国際会議の場において, 次期枠組 みについての議論が詰められていくこととなるが, 今回のサミットによって, 主要経済国において長 期目標や中期目標の設定について一定の同意を得 られたことは，大きな成果であったといえる。

\section{5. 我が国の地球温暖化対策への取組}

日本では，1990年に地球温暖化防止行動計画を 策定した後, 幾度かの行動計画の改定を経て, 温 暖化対策を強化してきた。主な取組としては，日 本が石油ショック以降取組を進めてきた省エネル ギーの推進や新エネルギーの導入, 原子力発電の
推進などが挙げられる。その結果, 例えば工場に おける製造設備の導入や，オフィス・家庭におけ る様々な機器, あるいは自動車の省エネルギー性 能は世界トップクラスのレベルにあり，また，太 陽光発電などの新エネルギーの導入も着実に進み つつある。

その一方で，2006年度の日本の温室効果ガスの 総排出量（確定值）は, 二酸化炭素に換算して約 13億4,000万トンであり, 京都議定書の規定による 基準年 (1990年度) の総排出量（12億6,100万トン） から，6.2\%増加している（図 4 ）。

温室効果ガスの排出の約 9 割を占めている二酸 化炭素については, その大半が産業部門（工場な ど）とエネルギー転換部門（発電所など）から排 出されている。特に, エネルギー転換部門の排出 量の増大が目立つ。(図 5 )

もっとも, 発電所から排出される二酸化炭素を, 
我が国の温室効果ガス排出量

2006年度における我が国の排出量は、基準年比6.2\%上回っており、 議定書の6\%削減約束の達成には、6.8\%の排出削減が必要。

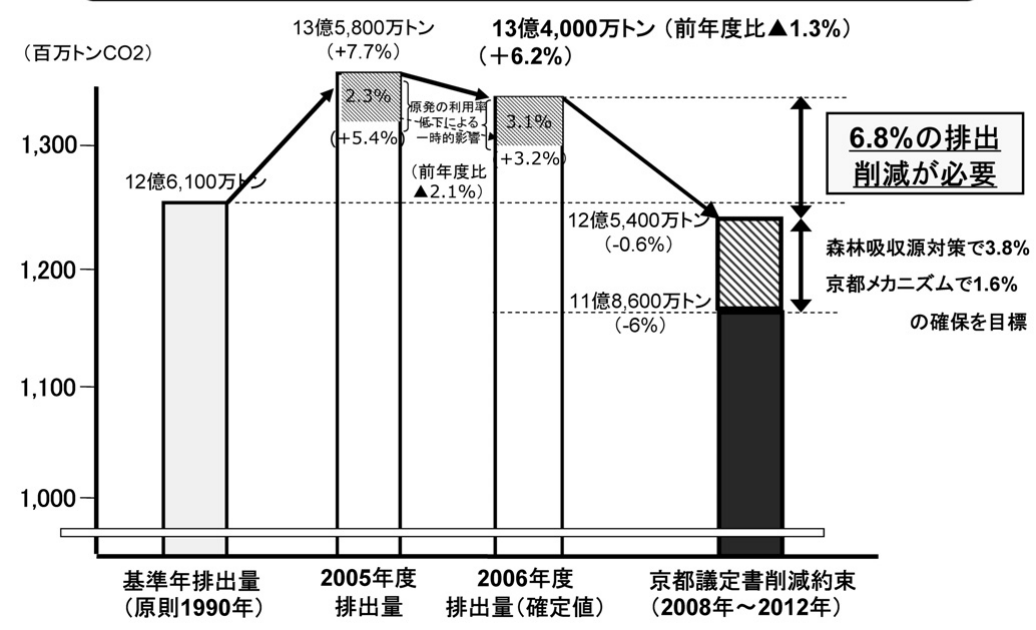

図 4：我が国の温室効果ガス排出量

$\mathrm{CO}_{2}$ の部門別排出量の推移（電熱配分前）

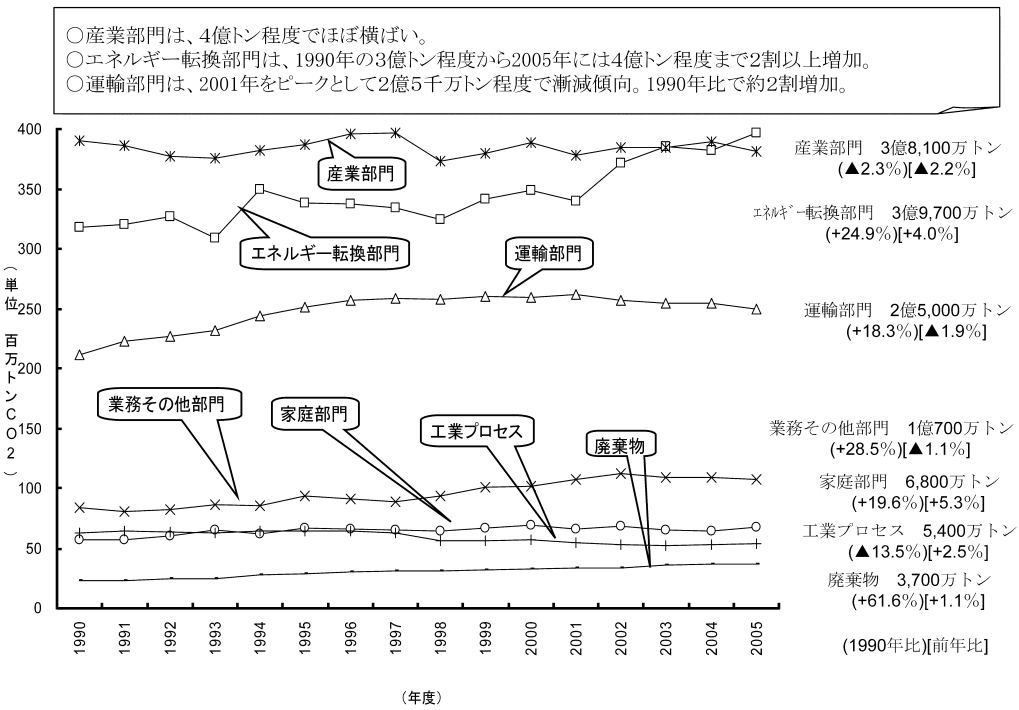

図 5：各部門別の排出量の推移（電熱配分前）

$<$ 出典 $>$ 温室効果ガス排出・収録目録

発電所ではなく, 電力を消費する場所に配分した 場合（図６）では，業務その他部門（オフィス・ 商店など）や家庭部門での排出量の増大が大きな
ウエイトを占めている。

日本において，温暖化対策への取組が進みつつ あるにもかかわらず，二酸化炭素排出量が減少し 
$\mathrm{CO}_{2}$ の部門別排出量の推移（電熱配分後）

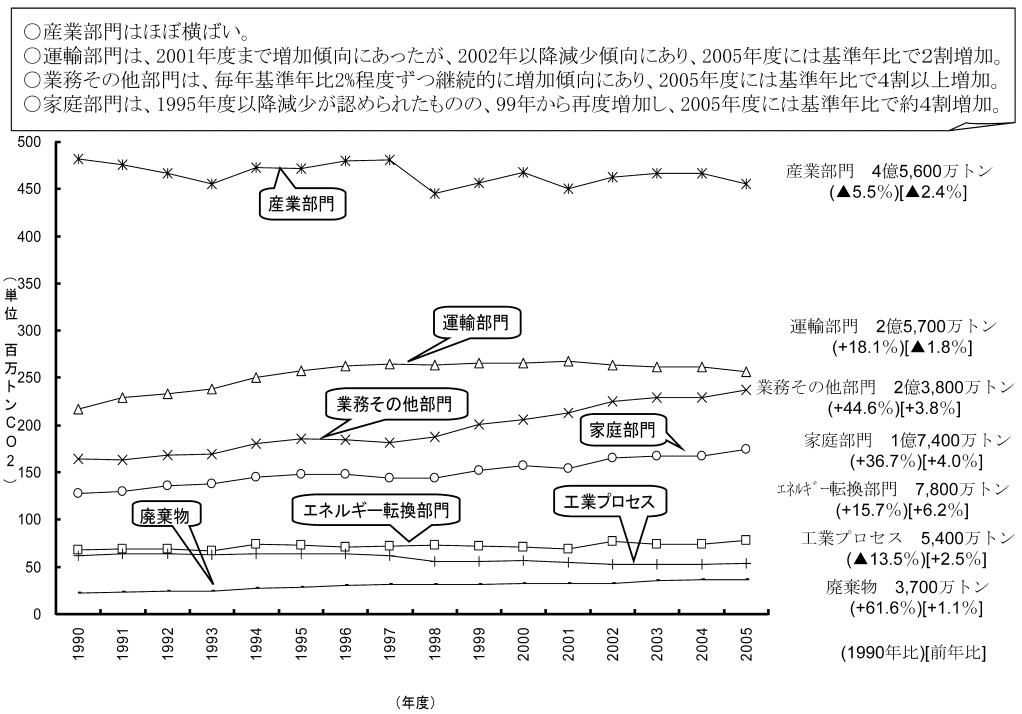

図 6：各部門別の排出量の推移（電熱配分後）

$<$ 出典 $>$ 温室効果ガス排出・収録目録

ないのは，様々な要因が考えられる。例えば，工 ネルギー転換部門における, 二酸化炭素を出さな い原子力発電所の稼働率の低下と, 二酸化炭素を 大量排出する石炭火力発電の増加, 業務部門 · 家 庭部門における活動量の増大などの影響が大きい と考えられる。

現時点では基準年度（1990年度）比で6.2\%増大 しているので, 日本における京都議定書の目標で ある基準年比マイナス $6 \%$ を達成するためには, これから $12.2 \%$ 削減することが必要となる。ただ し，そのうちの $3.8 \%$ 分については，森林による吸 収（シンク）によって賄うことが国際的に認めら れている。また, 1.6\%分については, 京都議定書 で認められたCDM (クリーン開発メカニズム) な どのいわゆる京都メカニズムを活用し, 海外から 温室効果ガスの排出枠を購入することとしている。 そのため, 今後実際に削減しなければならない排 出量は約 $7 \%$ に圧縮される(図 4 )。それでもなお, 京都議定書の目標達成は依然として容易ではない。
また，京都議定書の削減目標は，2008年から2012 年までの 5 年間の平均の排出量であることから, 排出削減が遅れれば遅れるほど，後から短期間で 大幅な削減を強いられることとなる。加えて，日 本が国際社会に対し提唱している，2050年に向け た長期目標や，京都議定書以降の中期的な削減を 考えれば, 我が国自身, 京都議定書以降も, 継続的・ 長期的に大幅な削減を達成しなければならない。

このように，日本の温暖化対策はもはや待った なしの状況である。排出削減を図るためには，排 出量が増大しているエネルギー転換部門や業務部 門，家庭部門はもちろんのこと，排出量の大きな 割合を占める産業部門，運輸部門においても，取 組の強化が不可欠である。

政府では，まず確実に京都議定書の $6 \%$ 削減目 標を達成するため，日本の温暖化対策の基本とな る計画（京都議定書目標達成計画）を2008年 3 月 に改定した (※ 5$)$ 。その結果, これまでの取組に 加えて, 例えば, 
○政府による厳格なチェックの下での, 企業に おける自主的な計画による温室効果ガスの削 減への取組（自主行動計画）の強化,

○省エネルギー法の改正（※6）などによる工 場・事業場や住宅・建築物の省エネルギー規 制の強化, トップランナー制度の拡充による 機器・自動車の省エネ性能の更なる向上,

○地球温暖化対策推進法の改正（※7）による, 事業者に対する取組強化の推進（事業者向け 指針の策定・公表や温室効果ガス排出量算定・ 報告・公表制度の対象拡大）や, 一定規模以 上の地方公共団体における計画策定の義務付 け,

など，自主的手法や規制的手法（法規制等）をは じめさまざまな政策手法を駆使し，産業部門，業 務部門，家庭部門を含め，あらゆる分野にわたっ て対策の強化が図られることとなっている。

今回の対策の強化によって，2010年には $6 \%$ 削 減目標は達成し得ると考えられている（※ 8$)$ 。 もっとも, 今後, 対策が予定どおりに進まない場 合や, 社会経済動向が想定と異なる場合には, 達 成が困難になることも予想される。そのため，今 回の改定以降も, 毎年 2 回, 計画の進渉状況を厳 格にチェックするとともに，2009年には，再度計 画全体を見直して, 必要があれば対策の追加・強 化を行うこととしている。

\section{6. 今後の我が国の取組について}

我が国は，2007年 6 月に環境立国戦略を策定 し (※9)，日本がこれまで培ってきた技術，人材， 経験を活かし, 環境問題に積極的に対応すること で，新たなビジネスチャンスや社会の活力を生み 出すことを目指すこととしている。

特に, 地球温暖化問題への取組については, 次 世代のための環境の保全はもちろん，日本の経済 成長や地域の活性化, 国際貢献にもつなげていく ことが考えられている。そのため, クールアース 50 や北海道洞爺湖G8サミットにおける取組に見 られるように，日本の強みを活かした戦略的かつ 能動的な対応を進めている。

しかしながら, 我が国の主張が国際社会に受け 入れられるためには，まずもって我が国自身が率 先して温暖化対策へ取り組み, 環境と経済が両立 した低炭素社会を実現し，世界に範を示さなけれ ばならない。

よって, 今後, $6 \%$ 削減目標の達成は言うまでも なく, 長期的・継続的かつ大幅な排出削減を実現 することが不可欠であり，そのためには，ライフ スタイル・ビジネススタイルの転換や, 低炭素型 の都市・交通などの構築, 技術開発の促進が必要 となってくる。

そのための政策として，市場メカニズムを活用

※ 5 ：改定京都議定書目標達成計画（平成20年 3 月 28日閣議決定）

http://www.env.go.jp/press/press.php?serial=9547

※ 6 : エネルギーの使用の合理化に関する法律の一部を改正する法律（平成20年 5 月 30 日公布）

http://www.meti.go.jp/press/20080304002/20080304002.html

※ 7 : 地球温暖化対策の推進に関する法律の一部を改正する法律（平成20年 6 月 13 日公布）

http://www.env.go.jp/press/press.php?serial=9435

※ 8 : ただし, 環境省・経済産業省の審議会委員やN P Oの一部からは, 今回の計画改定が数字合わせに過ぎず, 不十分で あるとの批判が寄せられている。

http://www.kikonet.org/iken/kokunai/2008-03-28.html（気候ネットワークホームページ）

http://www.isep.or.jp/news\&topics.html（環境エネルギー政策研究所2008年 1 月10日付けプレスリリース；12月21日開催 の中央環境審議会地球環境部会・産業構造審議会環境部会地球環境小委員会第30回合同会合の終了後, 研究者・NGOなど の委員・意見陳述人 ( 8 名) によるコメント)

$※ 9: 21$ 世紀環境立国戦略（平成19年 6 月 1 日閣議決定）（環境省ホームページ）

http://www.env.go.jp/guide/info/21c_ens/index.html 
した経済的手法である「国内排出量取引制度」(※ 10）や「環境税（税制のグリーン化）」, 法規制や 補助制度を通じた「太陽光発電などの新エネル ギーの大幅導入」, 消費者に温室効果ガスの情報を 提供し, 低炭素型の製品・サービスの購入を促す 「温室効果ガスの見える化」(※11) などが有効であ ると考えられる。

こうした取組については, 本年 6 月に福田総理 が示したいわゆる福田ビジョンや, 7 月に閣議決 定された低炭素社会づくり行動計画（※12）の中 で，積極的に検討を進めることとされたところで あり, 今後, このような取組の検討を政府一体と なって加速していく予定である。

他方で，規制や経済的負担が伴うこれらの取組 については，消極的な意見も根強く見られる。し かし, 二酸化炭素を大量に排出する個人・企業を
排出抑制に誘導し，地球温暖化防止のために二酸 化炭素の排出を抑制しようと日々努力している個 人・企業が報われるような仕組みとして，このよ うな取組を進めていくことが必要である。今後, 日本が低炭素社会を構築し, 環境立国として世界 に確固たる地位を築くためには，あらゆる政策を 導入し, 社会経済構造を変革することが求められ る。その際，こうした取組が遅れれば遅れるほど， 世界全体の地球温暖化対策の取組が停滞し, 我が 国は地球温暖化対策における国際的な信頼を失い かねず，また，環境と経済が両立するような発展 の道筋を積極的に模索することに躊躇していると， 我が国にとって不利なルールが国際ルールとして 規定されるおそれがあり，経済的にも大きな不利 益を被りかねないリスクにも留意しなければなら ないだろう。

※10: 国内排出量取引制度については，今年の秋から施行的実施を開始することとされている。この施行的実施の経験を活 かしながら, 排出量取引制度を本格導入する場合に必要となる条件, 制度設計上の課題などを明らかにしていくこととされ ている。(「低炭素社会づくり行動計画」13頁)

※11：温室効果ガス排出量の「見える化」は，製品やサービスの製造・流通・使用・廃棄等の過程において，C O 2 などの 温室効果ガスがどれだけ排出されているかを, 製品・サービスに表示することにより, 消費者に, 温室効果ガスの排出量が より少ない製品・サービスあるいは事業の選択を促すことを目的としている。さらに，低炭素の（CＯ２が少ない）製品・ サービスを事業者が生み出すことで, 事業者自身の排出削減も促すこととなる。現在, 政府内において検討が進められてい る。

※12：低炭素社会づくり行動計画（平成20年 7 月29日閣議決定）

http://www.env.go.jp/press/press.php?serial=10025 